\title{
PENGEMBANGAN APLIKASI SMARTHAFIDZ MENGGUNAKAN METODE NAIVE BAYES (Studi Kasus Pondok Pesantren Darussalam Sidodadi)
}

\author{
Vivin Fitri Lestari ${ }^{1}$, Purnomo Hadi Susilo ${ }^{2}$, Agus Setia Budi ${ }^{3}$ \\ ${ }^{1,2,3)}$ Program Studi Teknik Informatika, Fakultas Teknik, Universitas Islam Lamongan \\ Jl. Veteran No. 53 A Lamongan \\ Telp. (0322) 324706 , Fax. 0322324706 \\ E-mail:vivinfitril@yahoo.com ${ }^{1}$,purnomo@unisla.ac.id ${ }^{2}$, geniusbudi@unisla.ac.id ${ }^{3}$
}

\begin{abstract}
ABSTRAK
Pondok Pesantren Darussalam Sidodadi adalah sebuah lembaga pendidikan yang menerapkan sistem tahfidz untuk siswa siswinya. Namun, situasi yang dihadapi Pondok Pesantren saat ini adalah pada proses pembelajaran yang kadang terhambat dikarenakan salah satu pengajar atau murid yang tidak bisa hadir pada proses pembelajaran atau pada saat pengujian hafalan sehingga membuat jadwal ujian menjadi terlambat dari waktu yang telah ditentukan. Melalui sistem aplikasi berbasis android para murid bisa belajar secara online melalui smartphone masing-masing. Pada pengujian hafalan murid bisa menjawab melalui suara secara langsung. Berdasarkan data penilaian yang telah diperoleh, rata-rata penilaian hafalan mempunyai tiga kriteria seperti kelancaran membaca, ketepatan membaca dan ketepatan waktu, sehingga penulis memutuskan untuk menggunakan model Speech To Text dengan metode Naive Bayes untuk menentukan penilaian akhir. Hasil penelitian yang diperoleh oleh penulis bahwa model Speech To Text bisa mengubah suara menjadi sinyal dan dengan Metode Naive Bayes bisa menghasilkan nilai keseluruhan yang akurat dan sesuai dengan konsep aplikasi yang telah dibuat. Tingkat akurasi hafalan Al-Quran yang diperoleh dari murid yang memakai aplikasi dan yang tidak menggunakan aplikasi yang didapat sebesar $86,6 \%$.
\end{abstract}

Kata Kunci: Speech To Text, Naive Bayes

\section{ABSTRACT}

Darussalam Islamic Boarding School Sidodadi is an educational institution that implements the Tahfidz system for their students. However, the situation facing Islamic boarding school today is in the learning process which is sometimes hampered due to one of the teachers or students who cannot be present during the learning process or during rote testing so as to make the exam schedule late from the allotted time. Through an androidbased application system students can learn online through their respective smartphone In rote testing students can answer by voice directly. Based on the assessment data that have been obtained, the average memorization assessment has three criteria such as fluency in reading, reading accuracy and timeliness, so the author decided to use the Speech To Text model with the Naive Bayes method to determine the final assessment. The research results obtained by the author that the Speech To Text model could convert sounds into signals and with the Naive Bayes Method could produced an overall value that was accurate and in accordance with the application concept that has been made. The accuracy of memorization of the Al-Quran obtained from students who used the application and who did not use the application obtained by $86.6 \%$.

Keyword: Speech To Text, Naive Bayes

\section{PENDAHULUAN}

\subsection{Latar Belakang}

Pondok Pesantren Darussalam Sidodadi merupakan salah satu lembaga pendidikan yang menerapkan sistem dimana santrinya tinggal dan belajar bersama dengan guru atau pengajarnya yang biasa disebut dengan kiai. Pondok Pesantren Darussalam Sidodadi ini berada di Jl.Masjid Darussalam, Dusun Sidodadi, Desa Kranji, Kecamatan Paciran. Pondok Pesantren Darussalam ini menerapkan sistem hafalan Al-Quran.

Sistem operasi android pada zaman sekarang ini sangat maju dan berkembang pesat. Zaman semakin berkembang dan dan sistem operasi android dari tahun ke tahun mengalami peningkatan sistem seiring dengan peningkatan kebutuhan dan jumlah pengguna yang semakin banyak. Hasil dari sistem operasi android pada smartphone dapat dijadikan sebagai sarana belajar yang mudah dimengerti serta menarik dipelajari dan praktis digunakan dimana saja.

Dapat disimpulkan dari permasalahan diatas bahwa penulis ingin membuat suatu aplikasi yang bisa digunakan oleh santri dalam menghafal AlQuran. Serta dapat menilai hafalan santri terhadap surat yang ada di Al-Quran. Melalui media suara yang ditangkap oleh aplikasi kemudian dilakukan penilaian apakah sudah sesuai dengan ayat yang ada 
di Al-Quran atau belum. Berdasarkan uraian diatas yang telah dijelaskan maka, penulis ingin mengambil judul "Aplikasi Hafalan Al-Quran Menggunakan Speech To Text Dengan Metode Naive Bayes" untuk menunjang belajar santri serta mengantisipasi terjadinya masalah tersebut.

\subsection{Referensi \\ 1.2.1 Speech to Text}

Dikenal juga sebagai pengenal suara otomatis (automatic speech recognition) atau pengenal suara koputer (computer speech recognition). Speech to text merupakan sebuah metode dimana, proses identifikasi yang dilakukan oleh komputer untuk mengenali suara atau ejaan yang diucapkan oleh pengguna tanpa melihat identitas pengguna tersebut. Dengan melakukan konversi sinyal akustik yang ditangkap oleh audio device (perangkat input suara). Pola kerja dari speech to text sendiri adalah mencocokan sinyal akustik yang diterima dengan data yang tersimpan pada database. (Fauzan, 2018:29).

Speech recognition digunakan untuk menggantikan peranan input dari keyboard dan mouse. Keuntungan menggunakan metode ini adalah kecepatan dan kemudahan dalam penggunaannya. Algoritma yang akan diimplementasikan pada proses speech recognition adalah algoritma FFT (Fast Fourier Transform), yaitu sebuah algoritma yang cukup efisien dalam memproses sinyal digital ( dalam hal ini suara) dalam bentuk diskrit. Algoritma ini mengimplementasikan algoritma Devide dan Conquer untuk pemrosesannya. Konsep utama algoritma ini adalah mengubah sinyal suara menjadi berbasis waktu menjadi berbasis frekuensi dengan membagi masalah yang menjadi beberapa upa masalah kecil. Setiap upa masalah diselesaikan dengan cara melakukan pencocokan pola digital suara. (Fauzan, 2018:34).

Speech Recognition digunakan untuk memproses sinyal suara dan mengubah menjadi sinyal digital. Hasil dari proses tadi di konversi menjadi bentuk spektrum suara yang akan di analisa dengan membandingkan dengan template suara yang ada pada database sistem. Sebelumnya, data suara yang telah dipilih dan di proses berdasarkan urutannya. Proses pertama yang dilakukan adalah memproses gelombang kontinu spektrum suara menjadi bentuk diskrit.(Ingrid: 2014). Langkah selanjutnya adalah proses kalkulasi yang dibagi menjadi dua bagian :

1. Transformasi gelombang diskrit mejadi array data.

2. Masing-masing elemen pada array data, dihitung "ketinggian" gelombang (frekuensi). Objek permasalahan yang akan dibagi adalah masukan $\mathrm{n}$, berupa data diskrit gelombang suara.

\subsubsection{Naive Bayes}

Naive Bayes clasification adalah sebuah metode pengklasifikasian probabilitas sederhana yang bisa digunakan untuk menghitung beberapa probabilitas dengan menambahkan frekuensi dan mengkombinasikan nilai dari suatu dataset yang telah diberikan. Algoritma yang memakai teorema bayes dan semua atribut yang berdiri sendiri atau tidak bergantung dan diberi oleh nilai pada variabel kelas. Naive Bayes adalah suatu metode yang mengklasifikasikan dengan sebuah metode probabilitas dan statistik atau bisa disebut dengan memprediksi sebuah peluang diwaktu yang akan datang berdasarkan dari pengalaman yang terjadi di waktu sebelumnya. Naive Bayes juga didasarkan dalam asumsi penyederhanaan dari nilai atribut secara kondisional yang bebas jika diberikan nilai output. (Ridwan : 2013:59-64).

Keuntungan dari menggunakan metode Naive Bayes adalah metode ini hanya menggunaka data pelatihan atau data training. Data training digunakan untuk menentukan parameter dalam sebuah proses pengklasifikasikan. Naive Bayes bisa digunakan jauh lebih baik dalam situasi nyata dibanding dengan apa yang diharapkan. Menurut Bustami (2013:127-146). Persamaan dari metode Naive Bayes adalah sebagai berikut: (Pattekari:2012:290-294).

Rumus 21 Probabilitas Bersyarat :

$$
P(H \mid X)=\frac{\mathrm{P}(\mathrm{X} \mid \mathrm{H}) \mathrm{P}(\mathrm{H})}{P(X)}
$$

Dimana :

$\mathrm{X}$ : Data dengan class yang belum diketahui $\mathrm{H}$ : Hipotesis data merupakan suatu class spesifik $\mathrm{P}(\mathrm{X} \mid \mathrm{H})$ : Probabilitas hipotesis $\mathrm{H}$ berdasar kondisi $\mathrm{X}$ (prosteriori probabilitas)

$\mathrm{P}(\mathrm{H})$ : Probabilitas hipotesis $\mathrm{H}$

$\mathrm{P}(\mathrm{X} \mid \mathrm{H})$ : Probabilitas $\mathrm{X}$ berdasarkan kondisi pada hipotesis

$\mathrm{P}(\mathrm{X}) \quad$ : Probabilitas X

\subsubsection{Pengertian Andorid}

Menurut Teguh Arifianto (2011:1), android adalah sebuah sistem operasi yang digunakan pada smartphone atau telepon pintar yang berbasis linux. Android merupakan sistem operasi yang dikembangkan oleh Google. Android bukan hanya digunakan untuk sistem operasi pada smartphone saja tetapi digunakan juga pada sistem operasi entertainment dan mobil. Hal ini dikarenakan android sudah mempunyai beberapa fitur penting seperti GPS dan itu gratis.

Android adalah sistem operasi mobile yang berkembang pada zaman dimana sistem operasi lain juga mengalami perkembangan yang sangat pesat. Sistem operasi seperti windows mobile, i-Phone OS, Symbian dan masih banyak lagi. Aplikasi yang berjalan dengan memprioritaskan aplikasi inti yang 
dibangun dengan tidak memperhatikan potensi atau kelebihan dari aplikasi pihak ketiga. adanya kekurangan dari aplikasi pihak ketiga digunakan untuk mendapatkan data asli dari ponsel dan keterbatasan distribusi pada aplikasi pihak ketiga untuk platform mereka. (Hermawan, 2011:1).

\subsection{Perancangan Proses}

Rancangan proses ini digunakan untuk menggambarkan bagaimana penguna menjalankan sistem. Berisi alur proses atau interaksi dengan sistem yang sedang dijalankan.

\section{Use Case Diagram}

Use Case Diagram adalah suatu komponen yang saling berhubungan dan membuat sistem secara teratur yang actor lakukan. Hubungan antara komponen-komponen tersebut yang dibuat pada sistem. Berikut adalah rancangan use case dari Aplikasi Hafalan Al-Quran disini akan dijelaskan bagaimana pengguna menjalankan program atau aplikasi hafalan Al-Quran sebagai berikut.

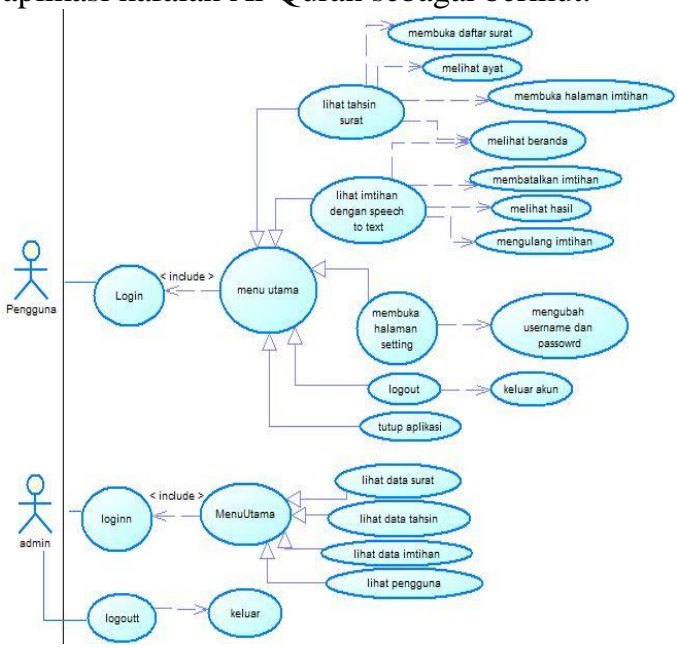

Gambar 1. Use case diagram

\section{Activity Diagram}

Activity Diagram adalah diagram yang menggambarkan aliran kerja atau aktifitas dari sebuah sistem atau atau aplikasi. Perlu diperhatikan bahwa diagram aktifitas menggambarkan aktivitas sistem bukan apa yang dilakukan aktor atau pengguna, jadi aktivitas yang dapat dilakukan oleh suatu sistem. Berikut adalah alur kerja pada Aplikasi Hafalan Al-Quran sebagai berikut.

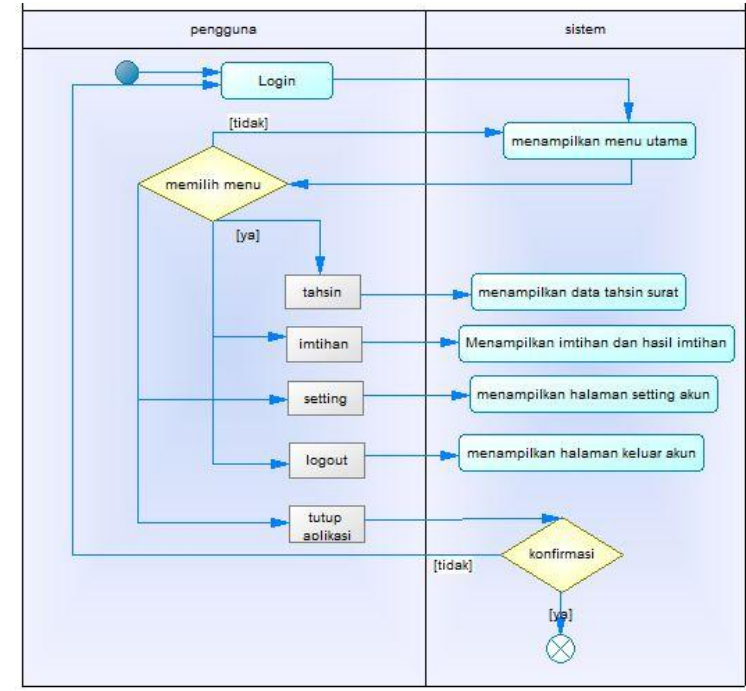

Gambar 2. Activity diagram

\section{Sequence Diagram}

Digunakan untuk menggambarkan atau menjelaskan alur kerja pada sistem yang sedang berjalan, sehingga menghasilkan hasil akhir tertentu. Sequence Diagram adalah interaksi antar objek dalam suatu sistem yang disusun pada sebuah urutan waktu yang disampaikan melalui pesan-pesan yang disampaikan sebagai berikut.

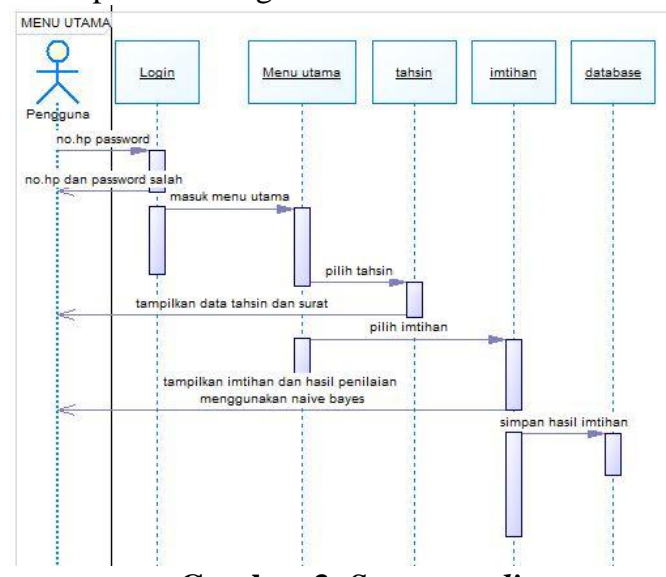

\subsection{Perancangan Basisdata}

Perancangan basisdata adalah suatu tahap yang digunakan untuk membuat tabel-tabel dalam database. Lebih lanjut (Susilo, 2019: 284) menjelaskan bahwa perancangan basisdata dalam pengembangan sebuah sistem merupakan hal yang sangat penting, karena berfungsi sebagai media penyimpanan seluruh data atau kegiatan yang ada pada sistem. Perancangan sebuah basisdata berisi tentang penjelasan data aplikasi bantu hafal AlQuran menggunakan speech to text dengan metode naive bayes berbasis android. Berikut merupakan tahapan perancangan data.

1. Conceptual Data Model (CDM)

Adalah sebuah konsep atau model yang berkaitan langsung dengan database. CDM dibuat dalam bentuk tabel-tabel yang menggambarkan suatu relasi 
antar setiap tabel yang diimplementasikan kedalam basis data.

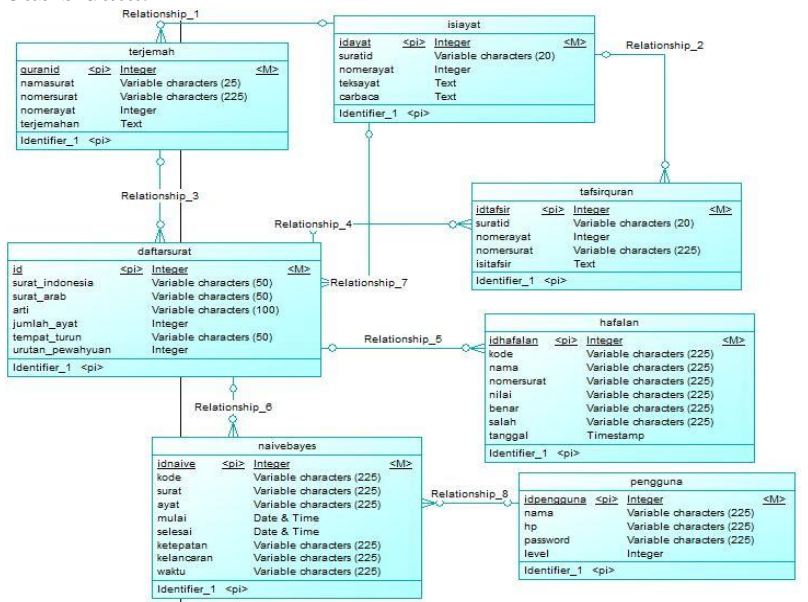

Gambar 4. Conceptual data model

\section{Physical Data Model (PDM)}

Adalah bentuk generate atau hasil dari Conceptual Data Model yang valid. PDM merupakan representasi fisik dari database yang sebenarnya. Rancangan dari Physical Data Model memuat desain tabel, struktur, tipe data dan juga relasi tiap tabel. Pada Physical Data Model terdapat hubungan atau relasi kardinalitas yang saling terhubung antar objek atau benda. Pada gambar dibawah ini terdapat enam entitas yang saling berhubungan. Pada enam entitas dibawah ini ada entitas terjemah, isiayat, tafsirquran, daftarsurat, naive bayes, hafalan dimana semuanya memiliki hubungan atau relasi satu sama lain.

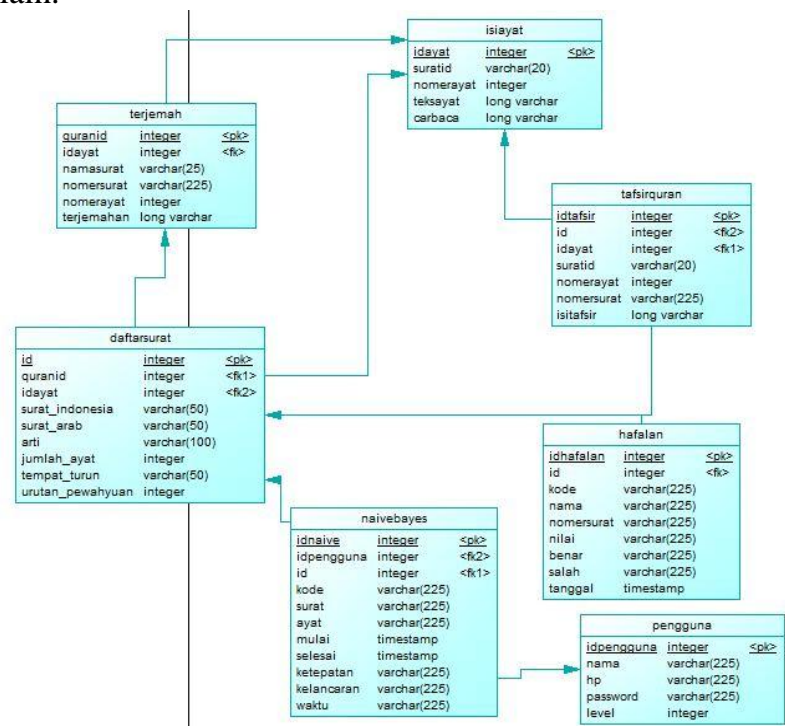

Gambar 5. Phycical data model

\subsection{Perancangan Interface}

Dalam perancangan desain interface dibuat sederhana agar pengguna dapat mengoprasikan dengan mudah.

1) Halaman Register

Halaman register adalah halaman awal saat pengguna belum memiliki akun. Pengguna mendaftarkan akun menggunakan nama, nomor $\mathrm{hp}$, dan juga password. Setelah pengguna mendaftar maka bisa langsung masuk ke halaman beranda.

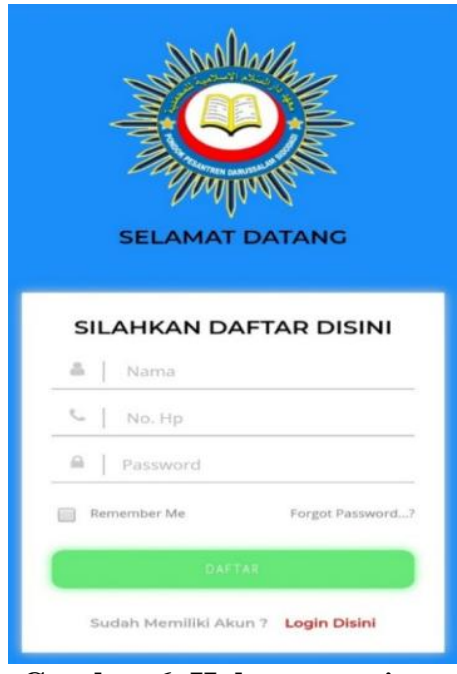

Gambar 6. Halaman register

2) Halaman Login

Halaman login adalah halaman awal ketika pengguna sudah memiliki akun. Jika pengguna telah keluar dari aplikasi kemudian masuk kembali maka diharuskan untuk menginputkan datra diri seperti nomor telepon dan pasword yang telah terdaftar pada aplikasi.

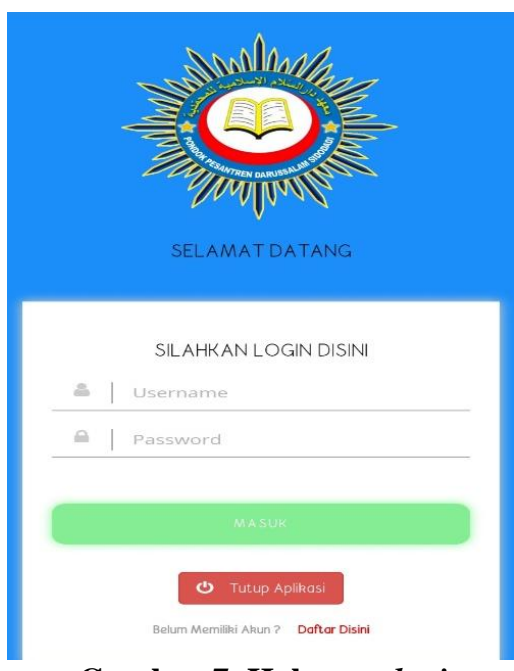

Gambar 7. Halaman login

3) Halaman Beranda

Halaman beranda adalah halaman awal yang dijalankan, pada halaman utama ini berisi menu yang ada pada aplikasi hafalan Al-Quran. Beranda berfungsi sebagai katalog tentang aplikasi yang berisi menu apa saja yang terdapat pada menu utama. 


\section{E-TAHFIDI}
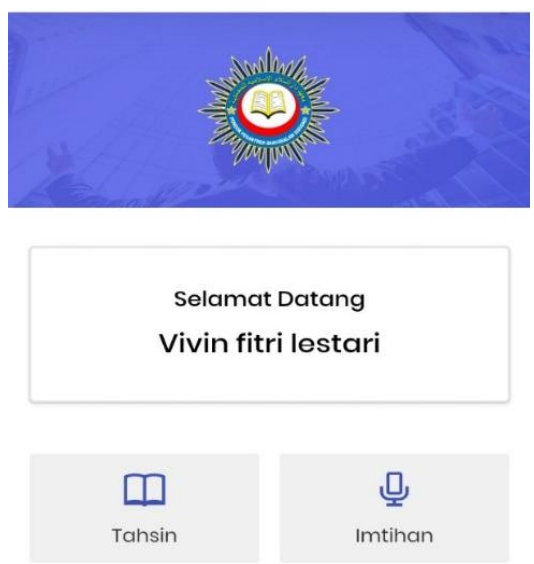

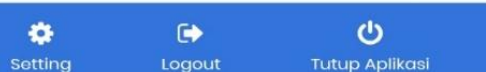

Gambar 8. Halaman beranda

4) Halaman Tahsin

Halaman surat dan tahsin berisi semua daftar nama surat yang ada di dalam Al-Quran. Dimana pada halaman ini pengguna bisa membuka surat sesuai dengan keinginannya. Pada halaman surat nama surat sudah disesuaikan berdasarkan urutannya dalam Al-Quran. Pengguna juga bisa membaca dan mendengarkan audio bacaan surat, karena sudah dilengkapi dengan text setiap ayat serta audio yang tersedia dan juga dilengkapi dengan arti atau kandungan isi surat

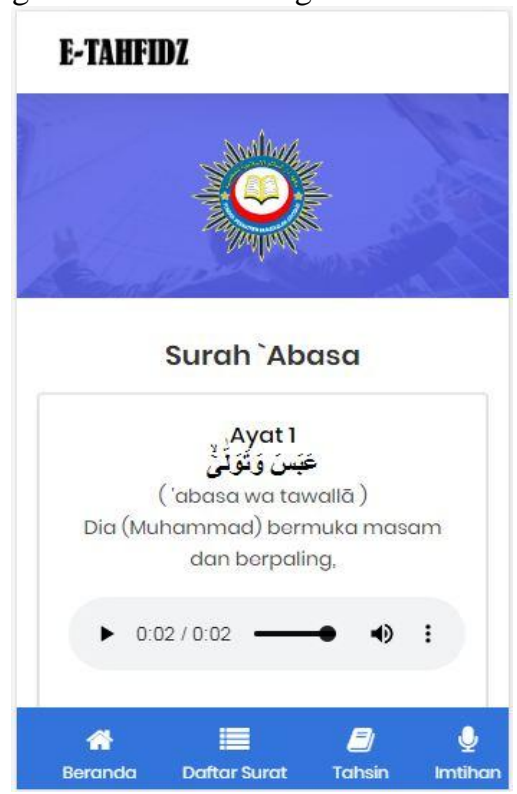

Gambar 9. Halaman tahsin

5) Halaman Imtihan

Halaman imtihan adalah halaman yang berarti ujian atau tes yang dijalani penggguna. Setiap pengguna akan di uji tingkat hafalannya melalui audio berupa sambung ayat.
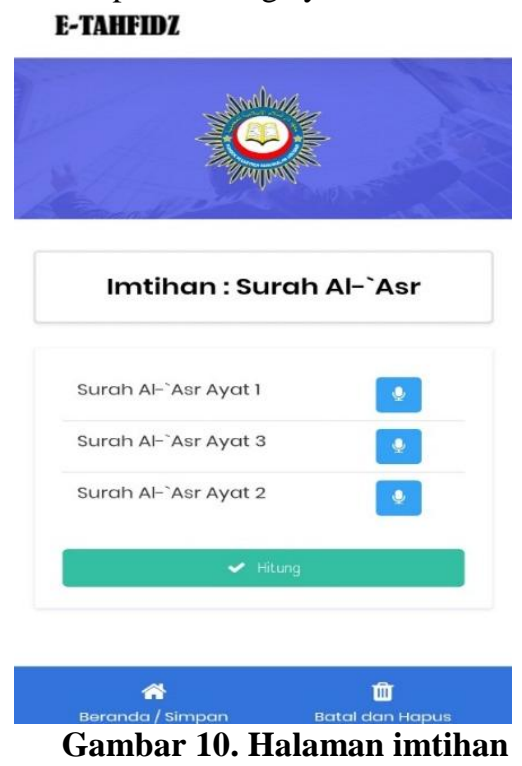

6) Halaman Proses Hitung Hasil Imtihan Pada proses hitung hasil imtihan pengguna bisa melihat keseluruhan nilai hafalan yang didapat. Penilaian didapat dari pembacaan setiap ayat yang di ujikan. Dalam kriteria penilain terdapat tiga indikator yakni kelancaran hafalan, ketepatan waktu hafalan dan juga ketepatan membaca.

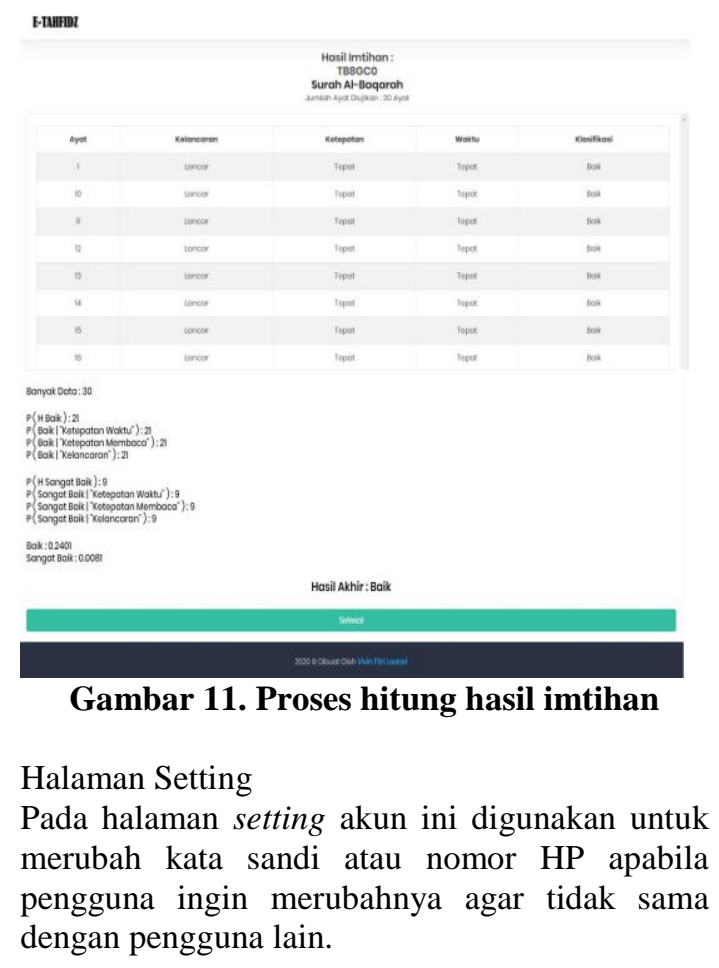




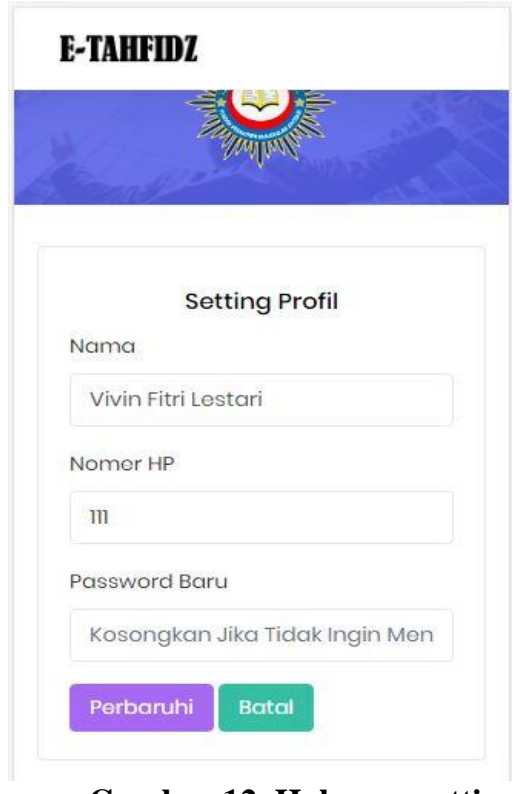

\section{Gambar 12. Halaman setting}

\section{HASIL DAN PEMBAHASAN}

Aplikasi yang dibuat digunakan untuk mempermudah pengguna dalam menghafal $\mathrm{Al}$ Quran. Sistem yang dibuat perlu dilakukan uji coba apakah sudah berfungsi dengan baik serta sesuai dengan rancangan yang telah dibuat. Pada penelitian yang penulis buat menerapkan metode naive bayes untuk menentukan tingkat akurasi antara suara denga ayat yang dibaca. adapun hasil uji coba sebagai berikut:

Tabel 1. Data hasil uji coba

\begin{tabular}{|c|c|c|c|}
\hline $\begin{array}{l}\text { Data } \\
\text { Masukan }\end{array}$ & $\begin{array}{l}\text { Hasil Yang } \\
\text { Diharapka } \\
\text { n }\end{array}$ & $\begin{array}{l}\text { Hasil Uji } \\
\text { Coba }\end{array}$ & $\begin{array}{l}\text { Hasil } \\
\text { pengujian }\end{array}$ \\
\hline $\begin{array}{l}\text { Menu } \\
\text { Utama }\end{array}$ & $\begin{array}{l}\text { Menampilka } \\
\mathrm{n} \text { halaman } \\
\text { menu utama }\end{array}$ & $\begin{array}{l}\text { Dapat } \\
\text { menampil } \\
\text { kan } \\
\text { halaman } \\
\text { manu } \\
\text { utama }\end{array}$ & Berhasil \\
\hline $\begin{array}{l}\text { Menu } \\
\text { surat }\end{array}$ & $\begin{array}{l}\text { Menampilka } \\
\text { n seluruh } \\
\text { daftar surat } \\
\text { yang ada di } \\
\text { Al-Quran }\end{array}$ & $\begin{array}{l}\text { Dapat } \\
\text { menampil } \\
\text { kan } \\
\text { seluruh } \\
\text { daftar } \\
\text { surat } \\
\text { dalam Al- } \\
\text { Quran } \\
\end{array}$ & Berhasil \\
\hline $\begin{array}{l}\text { Menu } \\
\text { Pencarian }\end{array}$ & $\begin{array}{l}\text { Menampilka } \\
\text { n pencarian } \\
\text { nama surat }\end{array}$ & $\begin{array}{l}\text { Dapat } \\
\text { menampil } \\
\text { kan } \\
\text { pencarian } \\
\text { nama } \\
\text { surat yang } \\
\text { dicari }\end{array}$ & Berhasil \\
\hline $\begin{array}{l}\text { Menu } \\
\text { tahsin }\end{array}$ & $\begin{array}{l}\text { Menampilka } \\
\text { n seluruh } \\
\text { tahsin atau } \\
\text { kandungan } \\
\text { surat yang }\end{array}$ & $\begin{array}{l}\text { Dapat } \\
\text { menampil } \\
\text { kan } \\
\text { seluruh } \\
\text { tahsin atau }\end{array}$ & Berhasil \\
\hline
\end{tabular}

\begin{tabular}{|c|c|c|c|}
\hline & $\begin{array}{l}\text { ada di Al- } \\
\text { Quran pada } \\
\text { setiap ayat }\end{array}$ & $\begin{array}{l}\text { kandunga } \\
\mathrm{n} \text { surat } \\
\text { yang ada } \\
\text { di Al- } \\
\text { Quran } \\
\text { pada } \\
\text { setiap ayat }\end{array}$ & \\
\hline $\begin{array}{l}\text { Menu } \\
\text { imtihan }\end{array}$ & $\begin{array}{l}\text { Menampilka } \\
\mathrm{n} \text { nama } \\
\text { surat yang } \\
\text { akan di uji } \\
\text { sesuai } \\
\text { dengan } \\
\text { pencarian } \\
\text { pengguna } \\
\text { kemudian } \\
\text { dapat } \\
\text { menampilka } \\
\text { n audio agar } \\
\text { pengguna } \\
\text { bisa } \\
\text { menjawab } \\
\text { melalui } \\
\text { audio } \\
\text { tersebut } \\
\text { serta dapat } \\
\text { menlihat } \\
\text { nilai } \\
\text { keseluruhan } \\
\text { hasil dari } \\
\text { hafalan }\end{array}$ & $\begin{array}{l}\text { Dapat } \\
\text { menam } \\
\text { nama } \\
\text { surat yang } \\
\text { akan din } \\
\text { uji sesuai } \\
\text { dengan } \\
\text { pencarian } \\
\text { pengguna } \\
\text { kemudian } \\
\text { dapat } \\
\text { menampil } \\
\text { kan audio } \\
\text { agar } \\
\text { pengguna } \\
\text { bisa } \\
\text { menjawab } \\
\text { melalui } \\
\text { audio } \\
\text { tersebut } \\
\text { serta dapat } \\
\text { melihat } \\
\text { nilai } \\
\text { keseleruha } \\
\text { n hasil } \\
\text { dari } \\
\text { hafalan }\end{array}$ & Berhasil \\
\hline 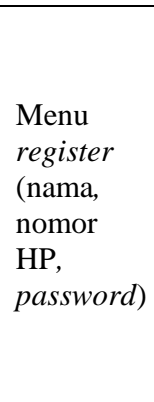 & $\begin{array}{l}\text { Menampilka } \\
\mathrm{n} \text { halaman } \\
\text { utama } \\
\text { pendaftaran } \\
\text { akun atau } \\
\text { profil } \\
\text { pengguna }\end{array}$ & $\begin{array}{l}\text { Dapat } \\
\text { menampil } \\
\text { kan } \\
\text { halama } \\
\text { utama } \\
\text { pendaftara } \\
\text { n akun } \\
\text { atau } \\
\text { pengisian } \\
\text { profil } \\
\text { pengguna }\end{array}$ & Berhasil \\
\hline $\begin{array}{l}\text { Menu } \\
\text { login } \\
\text { (nomor } \\
\text { HP, } \\
\text { password } \\
\text { ) }\end{array}$ & $\begin{array}{l}\text { Menampilka } \\
\text { n halaman } \\
\text { utama } \\
\text { pengguna }\end{array}$ & $\begin{array}{l}\text { Dapat } \\
\text { menampil } \\
\text { kan } \\
\text { halaman } \\
\text { utama } \\
\text { pengguna }\end{array}$ & Berhasil \\
\hline $\begin{array}{l}\text { Menu } \\
\text { setting } \\
\text { (nama, } \\
\text { nomor hp, } \\
\text { password } \\
\text { baru) }\end{array}$ & $\begin{array}{l}\text { Menampilka } \\
\text { n Pengisian } \\
\text { data } \\
\text { perubahan } \\
\text { profil } \\
\text { pengguna }\end{array}$ & $\begin{array}{l}\text { Dapat } \\
\text { menampil } \\
\text { kan } \\
\text { pengisian } \\
\text { data } \\
\text { perubahan } \\
\text { profil } \\
\text { pengguna }\end{array}$ & Berhasil \\
\hline $\begin{array}{l}\text { Menu } \\
\text { logout }\end{array}$ & $\begin{array}{l}\text { Keluar dari } \\
\text { beranda } \\
\text { aplikasi }\end{array}$ & $\begin{array}{l}\text { Dapat } \\
\text { menampil } \\
\text { kan } \\
\text { Keluar } \\
\text { dari } \\
\text { beranda } \\
\text { aplikasi }\end{array}$ & Berhasil \\
\hline
\end{tabular}


ISSN: 2503-071X

E-ISSN: 2621-511X

\subsection{Hasil Data Uji}

Hasil data uji merupakan hasil yang diperoleh melalui perhitungan dari metode naive bayes yang diterapkan oleh penulis. Berikut adalah hasil dari perhitungan pencocokan suara pada surat yasin yang diperoleh:

Tabel 2. Hasil data uji

\begin{tabular}{|c|c|c|c|c|}
\hline Nama & $\begin{array}{c}\text { Kelancar } \\
\text { an }\end{array}$ & $\begin{array}{c}\text { Ketepat } \\
\text { an } \\
\text { waktu }\end{array}$ & $\begin{array}{c}\text { Ketepata } \\
\text { n } \\
\text { membaca }\end{array}$ & $\begin{array}{c}\text { Klasif } \\
\text { ikasi }\end{array}$ \\
\hline $\begin{array}{l}\text { Surat } \\
\text { Yasin } \\
\text { Ayat 1 }\end{array}$ & Tepat & Lancar & Tepat & Baik \\
\hline $\begin{array}{c}\text { Surat } \\
\text { Yasin } \\
\text { Ayat } 2 \\
\end{array}$ & Tepat & Lancar & Tepat & Baik \\
\hline $\begin{array}{c}\text { Surat } \\
\text { Yasin } \\
\text { Ayat } 3\end{array}$ & Tepat & Lancar & Tepat & Baik \\
\hline $\begin{array}{c}\text { Surat } \\
\text { Yasin } \\
\text { Ayat } 4\end{array}$ & Tepat & Lancar & Tepat & Baik \\
\hline $\begin{array}{c}\text { Surat } \\
\text { Yasin } \\
\text { Ayat } 5\end{array}$ & Tepat & Lancar & Tepat & Baik \\
\hline $\begin{array}{c}\text { Surat } \\
\text { Yasin } \\
\text { Ayat } 6\end{array}$ & Tepat & Lancar & Tepat & Baik \\
\hline $\begin{array}{c}\text { Surat } \\
\text { Yasin } \\
\text { Ayat } 7\end{array}$ & Tepat & Lancar & Tepat & Baik \\
\hline $\begin{array}{l}\text { Surat } \\
\text { Yasin } \\
\text { Ayat } 8\end{array}$ & Tepat & Lancar & Tepat & Baik \\
\hline $\begin{array}{c}\text { Surat } \\
\text { Yasin } \\
\text { Ayat } 9\end{array}$ & Tepat & Lancar & Tepat & Baik \\
\hline $\begin{array}{c}\text { Surat } \\
\text { Yasin } \\
\text { Ayat } \\
10\end{array}$ & Tepat & Lancar & Tepat & Baik \\
\hline $\begin{array}{c}\text { Surat } \\
\text { Yasin } \\
\text { Ayat } \\
11 \\
\end{array}$ & Tepat & Lancar & Tepat & Baik \\
\hline $\begin{array}{l}\text { Surat } \\
\text { Yasin } \\
\text { Ayat } \\
12 \\
\end{array}$ & Tepat & Lancar & Tepat & Baik \\
\hline $\begin{array}{c}\text { Su } \\
\text { rat } \\
\text { Yasin } \\
\text { Ayat } \\
13 \\
\end{array}$ & Tepat & Lancar & Tepat & Baik \\
\hline $\begin{array}{c}\text { Surat } \\
\text { Yasin } \\
\text { Ayat } \\
14 \\
\end{array}$ & Tepat & Lancar & Tepat & Baik \\
\hline $\begin{array}{c}\text { Surat } \\
\text { Yasin } \\
\text { Ayat } \\
15 \\
\end{array}$ & Tepat & Lancar & Tepat & Baik \\
\hline
\end{tabular}

\begin{tabular}{|c|c|c|c|c|}
\hline $\begin{array}{c}\text { Surat } \\
\text { Yasin } \\
\text { Ayat } \\
16\end{array}$ & Tepat & Lancar & Tepat & Baik \\
\hline $\begin{array}{c}\text { Surat } \\
\text { Yasin } \\
\text { Ayat } \\
17 \\
\end{array}$ & Tepat & Lancar & Tepat & Baik \\
\hline $\begin{array}{c}\text { Surat } \\
\text { Yasin } \\
\text { Ayat } \\
18\end{array}$ & Tepat & Lancar & Tepat & Baik \\
\hline $\begin{array}{c}\text { Surat } \\
\text { Yasin } \\
\text { Ayat } \\
19\end{array}$ & Tepat & Lancar & Tepat & Baik \\
\hline $\begin{array}{c}\text { Surat } \\
\text { Yasin } \\
\text { Ayat } \\
20\end{array}$ & Tepat & Lancar & Tepat & Baik \\
\hline $\begin{array}{c}\text { Surat } \\
\text { Yasin } \\
\text { Ayat } \\
21\end{array}$ & Tepat & Lancar & Tepat & Baik \\
\hline $\begin{array}{c}\text { Surat } \\
\text { Yasin } \\
\text { Ayat } \\
22\end{array}$ & Tepat & Lancar & Tepat & $\begin{array}{c}\text { Sangat } \\
\text { Baik }\end{array}$ \\
\hline $\begin{array}{c}\text { Surat } \\
\text { Yasin } \\
\text { Ayat } \\
23 \\
\end{array}$ & Tepat & Lancar & Tepat & $\begin{array}{c}\text { Sangat } \\
\text { Baik }\end{array}$ \\
\hline $\begin{array}{c}\text { Surat } \\
\text { Yasin } \\
\text { Ayat } \\
24 \\
\end{array}$ & Tepat & Lancar & Tepat & $\begin{array}{c}\text { Sangat } \\
\text { Baik }\end{array}$ \\
\hline $\begin{array}{c}\text { Surat } \\
\text { Yasin } \\
\text { Ayat } \\
25\end{array}$ & Tepat & Lancar & Tepat & $\begin{array}{c}\text { Sangat } \\
\text { Baik }\end{array}$ \\
\hline $\begin{array}{c}\text { Surat } \\
\text { Yasin } \\
\text { Ayat } \\
26\end{array}$ & Tepat & Lancar & Tepat & $\begin{array}{c}\text { Sangat } \\
\text { Baik }\end{array}$ \\
\hline $\begin{array}{c}\text { Surat } \\
\text { Yasin } \\
\text { Ayat } \\
27\end{array}$ & Tepat & Lancar & Tepat & $\begin{array}{c}\text { Sangat } \\
\text { Baik }\end{array}$ \\
\hline $\begin{array}{c}\text { Surat } \\
\text { Yasin } \\
\text { Ayat } \\
28\end{array}$ & Tepat & Lancar & Tepat & $\begin{array}{c}\text { Sangat } \\
\text { Baik }\end{array}$ \\
\hline $\begin{array}{c}\text { Surat } \\
\text { Yasin } \\
\text { Ayat } \\
29 \\
\end{array}$ & Tepat & Lancar & Tepat & $\begin{array}{c}\text { Sangat } \\
\text { Baik }\end{array}$ \\
\hline $\begin{array}{c}\text { Surat } \\
\text { Yasin } \\
\text { Ayat } \\
30\end{array}$ & Tepat & Lancar & Tepat & $\begin{array}{c}\text { Sangat } \\
\text { Baik }\end{array}$ \\
\hline
\end{tabular}

Perhitungan Manual

Surah : yasin

ayat : 1 sampai 30

Parameter ditambahkan: 
1. kelancaran : lancar

2. ketepatan waktu : tepat

3. ketepatan membaca : tepat

4. klasifikasi : belum diketahui

$\mathrm{H}$ (Sangat Baik)

E (kelancaran, ketepatan waktu, ketepatan membaca)

$\mathrm{P}(\mathrm{H}$ sangat baik $)=9 / 30$

$\mathrm{P}(\mathrm{H}$ baik $)=21 / 30$

$P$ (sangat baik | "lancar") $=9 / 30$

P (baik | "lancar") $=21 / 30$

p (sangat baik | "tepat") $=9 / 30$

$P$ (baik | "tepat") $=21 / 30$

$\mathrm{P}$ (sangat baik | "tepat") $=9 / 30$

$P$ (baik | "tepat") $=21 / 30$

$\mathrm{P}($ sangat baik $)=9 / 30 * 9 / 30 * 9 / 30 * 9 / 30=$ $6,561 / 810,000=0,0081$

$\mathrm{P}($ baik $)=21 / 30 * 21 / 30 * 21 / 30 * 21 / 30=$ $194,481 / 810,000=0,2401$

Berdasarkan perhitungan manual yang diperoleh dengan menggunakan metode naive bayes nilai yang diperoleh pada surat yasin ayat 1 sampai 30 klasifikasi penilaian ayat yang didapat pada cluster sangat baik sebanyak 0,0081 dan cluster baik didapat sebanyak 0,2401 maka nilai masuk ke cluster "baik".

\subsection{Tingkat Akurasi}

Tingkat akurasi adalah sebuah tolak ukur untuk mengetahui kelayakan suatu sistem atau aplikasi yang dibuat. Berikut adalah tingkat akurasinya:

\section{Rumus 1. Tingkat Akurasi :}

Akurasi $=$

$\underline{\text { JumlahData Yang Diprediksi Secara Benar }}$ X

Jumlah Prediksi Yang Dilakukan

$100 \%$

$$
\begin{gathered}
\text { Akurasi }=\frac{26}{30} \times 100 \% \\
\text { Akurasi }=86,6 \%
\end{gathered}
$$

\section{KESIMPULAN}

Kesimpulan dari setiap tahap yang dilakukan seperti perancangan proses, implementasi dan pembahasan serta pengujian aplikasi hafalan AlQuran, kesimpulan yang dapat di ambil sebagai berikut:

1. Aplikasi hafalan Al-Quran pada Pondok Pesantren Darussalam Sidodadi telah berhasil dibuat sesuai dengan kebutuhan pengguna. Perancangan proses, mulai dari use case diagram, activity diagram, dan sequence diagram yang menjelaskan alur dari aplikasi yang dibuat. Perancangan desain interface untuk gambaran dari tampilan yang telah dibuat. Desain sistem selanjutnya bisa di implementasikan menggunakan Speech To text dan metode Naive Bayes.

2. Speech To Text bisa mendeteksi kelancaran dan ketepatan suara yang direkam. Metode Naive Bayes digunakan untuk menghitung penilaian hafalan sesuai dengan indikator penilaian hafalan yang telah ditentukan sehingga menghasilkan nilai sesuai dengan hafalan yang telah diujikan.

3. Tingkat akurasi diperoleh dengan cara menghitung jumlah data yang sesuai dengan banyak data sehingga diperoleh nilai akurasi sebanyak $86,6 \%$. Kemudian tingkat ketidaksesuaian atau error sebanyak 13,4\%. sehingga aplikasi hafalan Al-Quran menggunakan speech to text dengan metode naive bayes berbasis android sangat layak untuk digunakan pada Pondok Pesantren Darussalam Sidodadi.

5. Berdasarkan hasil pengujian aplikasi diketahui dalam mencari tingkat akurasi dari sistem yang sudah dibuat, dilakukan perbandingan hasil imtihan atau ujian tahfidz terhadap data aktual dimana data aktual tersebut adalah data hasil imtihan secara langsung tanpa menggunakan aplikasi. Dari perbandingan tersebut diperoleh hasil sebanyak $85,71 \%$. Dari hasil tersebut dapat diambil kesimpulan bahwa tingkat akurasi dari sistem yang sudah dibuat dibandingkan dengan keadaan secara langsung sudah cukup memuaskan dan layak untuk dipergunakan.

\section{PUSTAKA}

Arifianto, T. (2011). Membuat Interface Aplikasi Android Lebih Keren dengan LWUIT. Yogyakarta: Andi Publisher.

Arikunto, Prof. Dr. Suharsimi. (2010). Prosedur Penelitian Suatu Pendekatan Praktik. Jakarta: Rineka Cipta.

Fauzan A, Issa Arwani, Lutfi fanani. (2018). Pembangunan Aplikasi Iqro' Berbasis Android Menggunakan Google Speech. Jurnal Pengembangan Teknologi Informasi dan Ilmu Komputer, Vol.2, No.1, Hlm. 2935 .

Hermawan. (2011). Mudah Membuat Aplikasi Android. Yogyakarta: Andi Offset.

Ridwan M, Suyono H, Sarosa, M. (2013). Penerapan Data Mining Untuk Evaluasi Kinerja Akademik Mahasiswa Menggunakan Naive bayes Classifier. Jurnal EECCIS, Vol 1, No.7 hal. 59-64.

Susilo, P. H., \& Rohman, M. G. (2019). SISTEM PEMBELAJARAN ONLINE BERBASIS APLIKASI WEB MENGGUNAKAN FRAMEWORK CODEIGNITER. Joutica, 4(2), 281-286. 